Original Article

\title{
Pengaruh Kombinasi Terapi Akupresur dan Senam Nifas Terhadap Involusi Uteri Pada Ibu Nifas Di Praktik Mandiri Bidan
}

\section{The Effect of Combination of Acupressure Therapy and Puerperal Exercise to Uterine Involution in Puerperal Mother in Midwife Independent Practice}

\author{
Lailiyana*, Yan Sartika \\ Department of Midwifery Poltekkes Kemenkes Riau \\ (*lailiyana_skm@yahoo.co.id)
}

\begin{abstract}
ABSTRAK
Tujuan penelitian ini adalah untuk mengetahui pengaruh kombinasi terapi akupresur dan senam nifas terhadap involusi uteri pada ibu nifas di Praktik Mandiri Bidan Kota Pekanbaru. Jenis penelitian ini adalah penelitian analitik dengan desain kuasi eksperimen. Sampel berjumlah berjumlah 45 orang ibu nifas yang diambil dengan teknik incidental sampling dan dibagi menjadi 3 kelompok perlakuan. Hasil penelitian didapat bahwa rata-rata tinggi fundus uteri 1 minggu postpartum pada kelompok yang dilakukan kombinasi senam nifas dan akupresur lebih rendah yaitu 2,70 $\mathrm{cm}(\mathrm{SD}=1,236)$ dibanding kelompok yang dilakukan intervensi akupresur tanpa senam nifas yaitu $3,58 \mathrm{~cm}(\mathrm{SD}=1,269)$ dan yang dilakukan senam nifas tanpa akupresur yaitu $4,95 \mathrm{~cm}(\mathrm{SD}=1,575)$. Hasil uji anova pada derajat kepercayaan 95\% didapatkan ada perbedaan rata-rata tinggi fundus uteri antara kelompok ibu nifas yang dilakukan intervensi kombinasi akupresur dan senam nifas dengan kelompok yang dilakukan senam nifas tanpa akupresur $(\mathrm{p}=0,000)$, ada perbedaan rata-rata tinggi fundus antara kelompok ibu nifas yang dilakukan akupresur dengan kelompok yang dilakukan senam nifas $(\mathrm{p}=0.023)$, tidak ada perbedaan ratarata tinggi fundus antara kelompok ibu nifas yang dilakukan kombinasi akupresur dan senam nifas dengan kelompok yang dilakukan akupresur tanpa senam nifas $(\mathrm{p}=0,195)$. Kombinasi Terapi akupresur dan senam nifas lebih efektif mempercepat proses involusi.
\end{abstract}

Kata kunci: Nifas, Akupresur, Senam Nifas, Involusi

\begin{abstract}
The purpose of this study was to study the combination of acupressure therapy and puerperal exercise for the involvement of puerperal women in the Independent Midwife Practice of Pekanbaru City. This type of research was analytical research with a quasi-experimental design. Samples were taken from 45 postpartum mothers taken by incidental sampling technique and divided into 3 management groups. The results obtained an average height of fundus uteri 1 week postpartum in the group doing a combination of puerperal exercise and acupressure is lower that is $2.70 \mathrm{~cm}(\mathrm{SD}=1.236)$ compared to the group doing acupressure coverage without puerperal exercise which is $3.58 \mathrm{~cm}(\mathrm{SD}=1.269))$ and the puerperal exercise without acupressure is $4.95 \mathrm{~cm}(\mathrm{SD}=1.575)$. Anova test results at a $95 \%$ confidence level obtained found an average difference in the height of the fundus of uteri between the puerperal women group who carried out interventions combination of acupressure and puerperal exercise with a group that carried out puerperal exercise without acupressure $(p=0,000)$, there was an average difference height of fundus between groups of the puerperal women performed by acupressure and the group carried out puerperal exercise $(p=0.023)$, there was no difference in the average height of the fundus between the puerperal women group performed a combination of acupressure and puerperal exercise $(\mathrm{p}=0,195)$. The combination of acupressure therapy and puerperal exercise is more effective in increasing the involution process.
\end{abstract}

Key words: Puerperal, Acupressure, Puerperal Exercises, Involution

https://doi.org/10.33860/jik.v15i1.271

(C) 2021 by the authors. Submitted for possible open access publication under the terms and conditions of the Creative

Commons Attribution (CC BY SA) license (https://creativecommons.org/licenses/by-sa/4.0/). 


\section{PENDAHULUAN}

Masa nifas merupakan masa setelah lahirnya bayi dimana akan terjadi proses pemulihan alat-alat reproduksi kembali seperti sebelum hamil khususnya pada uterus yang disebut involusi. Selain itu, pada masa nifas yang tak kalah pentingnya adalah terjadinya proses laktasi yang sangat menentukan keberhasilan proses menyusui. Pemberian Air Susu Ibu (ASI) akan mempererat ikatan antara ibu dan bayi, peningkatan kualitas hidup bayi dan ibu serta mempengaruhi pertumbuhan dan perkembangan anak. Proses menyusui juga memberikan banyak manfaat bagi ibu, diantaranya adalah mempercepat proses involusi. ${ }^{1}$

Berbagai faktor yang mempengaruhi proses involusi yaitu mobilisasi dini, status gizi, usia, paritas dan proses menyusui. ${ }^{2}$. Mobilisasi diantaranya dapat dilakukan oleh ibu nifas adalah senam nifas dengan gerakan-gerakan tertentu pasca persalinan. Dengan melakukan senam nifas maka aliran darah akan meningkat dan lancar, sehingga mempengaruhi proses pengecilan rahim atau uterus akan kembali seperti kondisi sebelum hamil dengan bobot 60 gram. ${ }^{1}$

Selain senam nifas, asuhan lain yang bermanfaat bagi kesehatan ibu nifas adalah akupresur. Akupresur merupakan salah satu pengobatan komplementer yang dapat memperlancar ASI. Akupresur dapat membantu memaksimalkan reseptor prolaktin dan oksitosin serta meminimalkan efek samping dari tertundanya proses menyusui oleh bayi. ${ }^{3}$. Berbagai penelitian telah dilakukan tentang manfaat akupresur terhadap peningkatan volume ASI dan kelancaran proses menyusui. Namun penelitian terhadap pengaruh akupresur terhadap involusi uteri belum ada dilakukan. Selain memperbanyak ASI, dengan dilakukannya akupresur oksitosin yang dihasilkan dapat pula menyebabkan terjadinya kontraksi dan retraksi otot uteri sehingga akan menekan pembuluh darah yang mengakibatkan berkurangnya suplai darah ke uterus. Kontraksi uterus yang baik sangat diperlukan untuk mempercepat involusi uteri. Kontraksi akan membantu mengurangi situs atau tempat implantasi plasenta serta mengurangi perdarahan postpartum. ${ }^{4}$

Upaya yang terbukti membantu proses involusi uteri adalah dengan menganjurkan ibu nifas melakukan senam nifas. Senam nifas bermanfaat untuk memperbaiki sirkulasi darah, memperbaiki sikap tubuh dan punggung pasca persalinan, memperbaiki kekuatan otot panggul, otot perut, otot tungkai bawah, membantu ibu relaks dan segar pasca melahirkan. ${ }^{5}$. Berdasarkan pengalaman penulis pada saat melakukan bimbingan praktik klinik mahasiswa Jurusan kebidanan di klinik atau praktik mandiri bidan (PMB) yang ada di kota Pekanbaru yaitu Klinik Pratama Afiyah, PMB Dince Safrina dan PMB Siti Julaiha ditemukan upaya yang dilakukan oleh tenaga kesehatan untuk mempercepat proses involusi hanya dengan menganjurkan ibu postpartum melakukan mobilisasi berupa duduk dan jalan, tidak ada yang menganjurkan dan mengajarkan senam nifas kepada ibu postpartum.

Manfaat senam nifas terhadap percepatan proses involusi juga telah dibuktikan dari berbagai penelitian terdahulu yang dilakukan. Penelitian yang dilakukan oleh Rullynil, dkk tahun 2014 tentang "Pengaruh Senam Nifas terhadap Penurunan Tinggi Fundus Uteri pada Ibu Post Partum di RSUP DR. M. Djamil Padang" didapatkan hasil bahwa terdapat perbedaan yang signifikan penurunan tinggi fundus uteri antara kelompok yang dilakukan senam nifas dengan yang tidak dilakukan senam nifas pada hari ke-3 $(\mathrm{p}=0,000)$ dan hari ke 6 $(\mathrm{p}=0,000)$. Penelitian lain yang dilakukan oleh Munayarokh, dkk tentang "Proses Involusio Uterus pada Ibu yang Melaksanakan dan Tidak Melaksanakan Senam Nifas di Semarang" didapatkan hasil ada perbedaan proses involusi uteri pada ibu yang melaksanakan dan tidak melaksanakan senam nifas $(\mathrm{p}=0,000)$.

Penelitian tentang pengaruh senam nifas terhadap involusi uteri sudah banyak dilakukan, namun belum ada yang meneliti tentang pengaruh senam nifas yang di kombinasi terapi akupresur terhadap involusi uteri. Untuk itu penulis tertarik melakukan penelitian ini denagn tujuan untuk mengetahui pengaruh kombinasi terapi akupresur dan senam nifas terhadap involusi uteri pada ibu nifas di Praktik Mandiri Bidan Kota Pekanbaru

\section{METODE PENELITIAN}

Jenis penelitian ini adalah penelitian analitik dengan desain kuasi eksperimen. Populasi penelitian ini yaitu seluruh ibu nifas di Klinik Pratama Afiyah, PMB Dince Safrina dan PMB Siti Julaeha pada bulan Juni-Agustus 2019. Sampel berjumlah 45 orang yang diambil dengan teknik incidental sampling dan dibagi menjadi 3 kelompok perlakuan yaitu 15 ibu 
nifas untuk kelompok intervensi yang dilakukan kombinasi akupresur dan senam nifas, $15 \mathrm{ibu}$ nifas untuk kelompok intervensi akupresur dan 15 ibu nifas untuk kelompok intervensi senam nifas.

Intervensi dilakukan selama 7 hari berturut-turut. Senam nifas diberikan sesuai Standar Operasional Prosedur (SOP) senam nifas yang telah ditentukan (lampiran 7). Terapi akupresur dilakukan dengan penekanan pada 3 titik yaitu titik Large Intesitine 4 (LI4), titik Stomach 36 (ST 36) dan titik Small Intestine 1 (SI 1) masing-masing selama 60 detik. Penilaian involusi dengan mengukur tinggi fundus uteri menggunakan metlin pada hari pertama dan hari ke delapan. Pengumpulan data dengan metode observasi menggunakan instrumen lembar observasi. Analisis data menggunakan uji anova pada derajat kepercayaan $95 \%$..

\section{HASIL}

Pada tabel 1 menunjukkan bahwa ratarata tinggi fundus uteri hari pertama postpartum pada kelompok intervensi kombinasi akupresur dan senam nifas yaitu 12,93, kelompok intervensi akupresur 12,33 dan kelompok intervensi senam nifas 12,61 . Sedangkan ratarata tinggi fundus uteri 1 minggu postpartum pada kelompok intervensi kombinasi akupresur dan senam nifas yaitu 2,70, kelompok intervensi akupresur 3,58 dan kelompok intervensi senam nifas 4,95. Hasil uji anova pada derajat kepercayaan 95\% didapatkan tidak ada perbedaan rata-rata tinggi fundus uteri hari pertama antara kelompok intervensi kombinasi akupresur dan senam nifas, kelompok akupresur dan kelompok senam nifas $(\mathrm{p}=0,755)$ dan ada perbedaan rata-rata tinggi fundus uteri 1 minggu postpartum antara kelompok intervensi kombinasi akupresur dan senam nifas, kelompok akupresur dan kelompok senam nifas $(\mathrm{p}=0,000)$.

Pada tabel 2 menunjukkan bahwa hasil analisis lebih lanjut dengan uji Tukey didapatkan tidak ada perbedaan rata-rata tinggi fundus uteri 1 minggu postpartum pada kelompok intervensi kombinasi akupresur dan senam nifas dengan kelompok intervensi akupresur $(\mathrm{p}=0,195)$, dan ada perbedaan ratarata tinggi fundus uteri 1 minggu postpartum pada kelompok intervensi kombinasi akupresur dan senam nifas dengan kelompok intervensi senam nifas $(\mathrm{p}=0,000)$ serta ada perbedaan ratarata tinggi fundus uteri 1 minggu postpartum pada kelompok intervensi akupresur dengan kelompok intervensi senam nifas $(p=0,023)$

Tabel 1. Perbedaan Tinggi Fundus Uteri Pada ibu Nifas Berdasarkan Intervensi Kombinasi Akupresur dan Senam Nifas, Akupresur dan Senam Nifas di Praktik Mandiri Bidan Kota Pekanbaru

\begin{tabular}{|c|c|c|c|c|c|c|}
\hline & Intervensi & $\mathbf{n}$ & Mean & SD & $\mathbf{F}$ & $\begin{array}{c}\mathbf{p} \\
\text { value }\end{array}$ \\
\hline \multirow{3}{*}{$\begin{array}{l}\text { TFU } \\
1 \\
\text { hari } \\
\end{array}$} & Kombinasi akupresur dan senam nifas & 15 & 12.93 & 1.93 & \multirow{3}{*}{0,28} & \multirow{3}{*}{0,755} \\
\hline & Akupresur & 15 & 12.33 & 2.49 & & \\
\hline & Senam nifas & 15 & 12.61 & 2.08 & & \\
\hline \multirow{3}{*}{$\begin{array}{l}\text { TFU } \\
1 \\
\text { Minggu }\end{array}$} & Kombinasi akupresur dan senam nifas & 15 & 2.70 & 1.23 & \multirow{3}{*}{10,3} & \multirow{3}{*}{0,000} \\
\hline & Akupresur & 15 & 3.58 & 1.26 & & \\
\hline & Senam Nifas & 15 & 4.95 & 1.57 & & \\
\hline
\end{tabular}

Data Primer, 2019

Tabel 2. Signifikansi Perbedaan rata-rata Tinggi Fundus Uteri Antar Kelompok Intervensi Kombinasi Akupresur dan Senam Nifas, Akupresur dan Senam Nifas di Praktik Mandiri Bidan Kota Pekanbaru

\begin{tabular}{lcc}
\hline Intervensi & $\begin{array}{r}\text { TFU 1 hari (p } \\
\text { value) }\end{array}$ & $\begin{array}{c}\text { TFU 1 minggu(p } \\
\text { value) }\end{array}$ \\
\hline Kombinasi akupresur dan senam nifas vs akupresur & 0,734 & 0,195 \\
\hline $\begin{array}{l}\text { Kombinasi akupresur dan senam nifas vs Senam } \\
\text { nifas }\end{array}$ & 0,915 & 0,000 \\
\hline Akupresur vs Senam nifas & 0,934 & 0,023 \\
\hline
\end{tabular}




\section{PEMBAHASAN}

Masa Nifas merupakan masa dimana secara fisiologis seorang wanita akan mengalami proses pembentukan dan pengeluaran ASI (laktasi) serta terjadinya proses pemulihan organ reproduksi terutama rahim kembali mengecil kebentuk semula sebelum hamil atau yang disebut proses involusi. Kedua proses ini erat kaitannya dengan perubahan hormonal yang terjadi segera setelah proses persalinan. ${ }^{6}$. Hormon yang sangat berperan dalam proses laktasi dan involusi uteri adalah hormon oksitosin dan prolaktin. Hormon prolaktin akan merangsang pembentukan ASI dengan bantuan isapan bayi (letdown reflex) sedangkan hormon oksitosin akan membuat otot-otot payudara dan kapiler ASi untuk berkontraksi dan mengeluarkan ASI dari sinusnya. Disamping itu, hormon oksitosin menyebabkan terjadinya kontraksi dan retraksi otot uterus sehingga akan menekan pembuluh darah yang mengakibatkan berkurangnya suplai darah ke uterus. Proses ini membantu untuk mengurangi situs atau tempat implantasi plasenta, uterus akan mengecil serta mengurangi perdarahan. ${ }^{4}$

Banyak upaya yang dapat dilakukan agar proses involusi berjalan lancar dan normal yaitu diantaranya melakukan senam nifas. Senam nifas adalah latihan gerak yang dilakukan secepat mungkin setelah melahirkan supaya otot-otot yang mengalami peregangan selama kehamilan dan persalinan dapat kembali kepada kondisi normal seperti semula yang umumnya dilakukan enam jam setelah persalinan normal atau delapan jam setelah operasi Caesar. ${ }^{7}$ Upaya lain untuk mempercepat involusi dapat pula dilakukan yaitu merangsang pengeluaran oksitosin dengan terapi akupresur ${ }^{8}$. Pada saat dilakukan akupresur, pijatan dan stimulasi pada titik-titik tertentu pada tubuh maka aliran energi vital pada seluruh bagian tubuh akan lancar yang dapat mempengaruhi aliran darah, transportasi cairan-cairan tubuh, sistem syaraf, sistem hormonal, dan sistem getah bening. ' Pada penelitian ini setelah dilakukan intervensi kombinasi terapi akupresur dan senam nifas pada ibu nifas didapatkan bahwa rata-rata tinggi fundus uteri 1 minggu postpartum lebih rendah yaitu $2,70 \mathrm{~cm}$ dibanding kelompok ibu nifas yang dilakukan intervensi akupresur saja yaitu $3,58 \mathrm{~cm}$ dan yang dilakukan senam nifas saja tanpa akupresur yaitu $4,95 \mathrm{~cm}$. Hasil uji statistik juga membuktikan adanya perbedaan rata-rata tinggi fundus uteri pada 1 minggu post partum antara kelompok ibu nifas yang dilakukan intervensi kombinasi akupresur dan senam nifas dengan kelompok yang dilakukan senam nifas saja $(\mathrm{p}=0,000)$, serta ada perbedaan rata-rata tinggi fundus pada hari ke 8 antara kelompok ibu nifas yang dilakukan akupresur dengan kelompok yang dilakukan senam nifas $(\mathrm{p}=0.023)$. Sementara itu, hasil uji statsitik menyatakan bahwa tidak ada perbedaan ratarata tinggi fundus antara kelompok ibu nifas yang dilakukan kombinasi akupresur dan senam nifas dengan kelompok yang dilakukan akupresur tanpa senam nifas $(\mathrm{p}=0,195)$.

Penelitian tentang pengaruh akupresur terhadap involusi uteri belum ada dilakukan, namun hasil penelitian ini diperkuat oleh penelitian terdahulu tentang manfaat akupresur bagi kesehatan ibu nifas yang telah dilakukan oleh Rahayu D., dkk pada tahun 2015 di Kediri tentang "Produksi asi ibu dengan intervensi acupresure point for lactation dan pijat oksitosin" dengan mengambil sampel $27 \mathrm{ibu}$ postpartum primipara yang hasilnya menunjukkan bahwa ada perbedaan produksi ASI yang signifikan antara Acupressure Points for Lactation, pijat oksitosin dan kelompok kontrol $(\mathrm{p}=0,000)$. Dapat dijelaskan bahwa melalui pemberian tekanan atau pijatan lembut di titik-titik tertentu yang sesuai dengan acupoints pada tindakan akupresur akan merangsang produksi hormon prolaktin dan oksitosin. Kedua hormon ini berperan dalam pembentukan dan pengeluaran ASI. ${ }^{3}$. Selain memperlancar pengeluaran ASI, oksitosin yang dihasilkan dapat pula menyebabkan terjadinya kontraksi dan retraksi otot uteri sehingga akan menekan pembuluh darah yang mengakibatkan berkurangnya suplai darah ke uterus. Kontraksi uterus yang baik sangat diperlukan untuk mempercepat involusi uteri ${ }^{10}$. Kontraksi akan membantu mengurangi situs atau tempat implantasi plasenta serta mengurangi perdarahan postpartum. ${ }^{4}$.

Manfaat senam nifas bagi kesehatan ibu nifas khususnya terhadap penyembuhan alatalat reproduksi termasuk involusi uterus telah dibuktikan dari beberapa penelitian, namun penelitian tentang manfaat akupresur bagi proses involusi uteri belum ada dilakukan. Beberapa penelitian telah membuktikan manfaat akupresur terhadap produksi ASI dengan mekanisme pembentukan dan pengeluaran ASI akan lebih lancar akibat penekanan pada titik titik tertentu pada bagian tubuh merangsang pengeluaran hormon 
oksitosin dan prolaktin ${ }^{11}$. Pada penelitian ini, efek rangsangan pengeluaran oksitosin ini dikaitkan dengan kontraksi dan retraksi otot uterus yang efektif sehingga akan menekan pembuluh darah yang mengakibatkan berkurangnya suplai darah ke uterus. Proses ini membantu untuk mengurangi situs atau tempat implantasi plasenta dan dengan sendirinya rahim akan mengecil ${ }^{12}$. Pernyataan tersebut diatas didukung juga oleh penelitian yang dilakukan oleh Cholifah pada tahun 2014 di Kecamatan Mungkid didapatkan hasil bahwa teknik akupresur dapat meningkatkan pengeluaran dan produksi ASI. Penekanan pada titik-titik akupresur dapat meningkatkan hormone prolaktin dan oksitosin sehingga produksi dan pengeluaran ASI lancer serta dapat mempercepat proses involusi uteri ${ }^{13}$. Penelitian tentang manfaat senam nifas terhadap involusi diantaranya adalah penelitian yang dilakukan oleh Rullynil, dkk tahun 2014 tentang "Pengaruh Senam Nifas terhadap Penurunan Tinggi Fundus Uteri pada Ibu Post Partum di RSUP DR. M. Djamil Padang" didapatkan hasil bahwa terdapat perbedaan yang signifikan penurunan tinggi fundus uteri antara kelompok yang dilakukan senam nifas dengan yang tidak dilakukan senam nifas pada hari ke-3 $(\mathrm{p}=0,000)$ dan hari ke $6(\mathrm{p}=0,000)$. Penelitian lain yang dilakukan oleh Munayarokh, dkk tentang "Proses Involusi Uterus pada Ibu yang Melaksanakan dan Tidak Melaksanakan Senam Nifas di Semarang" didapatkan ada perbedaan proses involusi uteri pada ibu yang melaksanakan dan tidak melaksanakan senam nifas $(\mathrm{p}=0,000){ }^{14}$

Kontraksi otot uterus sama halnya dengan kontraksi otot polos lainnya dicetuskan oleh faktor perangsang yang bekerja langsung pada perangsang kontraksi otot polos dan tanpa potensial aksi. Faktor perangsang yang bersifat non saraf dan non potensial aksi yang paling sering adalah faktor kimiawi jaringan setempat dan bermacam-macam hormon. Didalam otot polos berjalan pembuluh darah arteri, vena dan pembuluh kapiler. Makin kecil pembuluh darah makin sedikit suplai sarafnya atau justru tidak ada sama sekali. Namun otot polos bersifat sangat kontraktil yang berespon cepat terhadap perubahan kimiawi setempat dalam cairan interstisial sekitarnya. Proses ini bisa terjadi pada saat ibu nifas melakukan senam nifas maka otot uterus akan mengalami kekurangan oksigen, terjadi peningkatan karbon diaoksida serta penumpukan asam laktat akibat aktivitas otot saat melakukan senam sehingga menyebabkan vasodilatasi pembuluh darah. Dengan demikian peredaran darah akan lancar dan memperkuat kontraksi otot uterus yang akhirnya mempercepat proses involusi. ${ }^{15}$.

Proses involusi yang dibuktikan lebih cepat pada penelitian ini yaitu dengan melakukan tambahan terapi akupresur selain senam nifas pada ibu nifas. Tentu saja hal ini akan berpengaruh lebih kuat terhadap kontraksi otot uterus. Seperti yang telah dijelaskan sebelumnya bahwa terapi akupresur akan merangsang pengeluaran hormon oksitosin. Dinyatakan bahwa kebanyakan hormon yang bersirkulasi dalam tubuh akan mempengaruhi kontraksi otot polos hingga derajat tertentu, dan beberapa diantaranya berpengaruh sangat besar. Diantara hormon yang berpengaruh sangat besar adalah hormon oksitosin. ${ }^{15}$. Saat ibu nifas diberikan intervensi akupresur maka penekanan pada titik ST 36, LI 4 dan SI 1 akan merangsang pengeluaran hormon endorphin dan oksitosin. Reseptor hormon oksitosin pada membran otot polos uterus akan membuka kanal ion kalsium dan natrium serta menimbulkan depolarisasi membrane yang membuat ion kalsium masuk kedalam sel sehingga terjadilah kontraksi. ${ }^{12}$.

Berdasarkan hasil penelitian ini dapat dilihat bahwa senam nifas dan terapi akupresur bermanfaat dalam membantu mempercepat proses involusi uteri. Hasil penelitian ini membuktikan bahwa apabila kedua intervensi ini dilakukan bersamaan maka hasil asuhan akan lebih baik, ditandai dengan rata-rata penurunan tinggi fundus uteri yang lebih cepat pada hari ke delapan sehingga memungkinkan uterus akan kembali seperti sebelum hamil dalam waktu 10 hari.

\section{KESIMPULAN DAN SARAN}

Senam Nifas dan akupresur bermanfaat dalam membantu proses involusi uteri. Dibanding senam nifas, akupresur lebih bermanfaat dalam mempercepat proses involusi uteri yang dibuktikan dengan hasil uji statistik bahwa adanya perbedaan rata-rata tinggi fundus uteri antara kelompok ibu nifas yang dilakukan intervensi kombinasi akupresur dan senam nifas dengan kelompok yang dilakukan senam nifas tanpa terapi akupresur $(\mathrm{p}=0,000)$, serta ada perbedaan rata-rata tinggi fundus uteri antara kelompok ibu nifas yang dilakukan akupresur dengan kelompok yang dilakukan senam nifas $(\mathrm{p}=0.023)$. Rata-rata tinggi fundus uteri pada kelompok ibu nifas yang dilakukan kombinasi 
akupresur dan senam nifas lebih rendah yaitu $2,70 \mathrm{~cm}$ dibanding kelompok ibu nifas yang dilakukan intervensi akupresur tanpa senam nifas yaitu $3,58 \mathrm{~cm}$ dan yang dilakukan senam nifas tanpa akupresur yaitu $4,95 \mathrm{~cm}$.

\section{DAFTAR PUSTAKA}

1. Cunningham FG. Obstetri Williams. Cetakan 23. Jakarta: EGC; 2012.

2. Mitayani. Asuhan keperawatan maternitas. Jakarta: Salemba Medika; 2011.

3. Rahayu D, Santoso B, Yunitasari E. Produksi Asi Ibu dengan Intervensi Acupresure Point for Lactation dan Pijat Oksitosin. Ners. 2015;10(1):9-19.

4. Varney H. Buku Saku Asuhan Kebidanan Varney Edisi 2. Jakarta: EGC; 2010.

5. Yanti D. Asuhan Kebidanan Masa Nifas. Cimahi: PT. Radika Aditama; 2011.

6. Dewi V. Asuhan Kebidanan Ibu Nifas. Jakarta: Salemba Medika; 2011.

7. Yuliarti N. Keajaiban ASI: Makanan Terbaik untuk Kesehatan, Kecerdasan dan Kelincahan Si Kecil. Yogyakarta: Andi; 2010.

8. Khabibah L, Mukhoirotin M. Pengaruh Terapi Akupresur Dan Pijat Oksitosin Terhadap Peningkatan Produksi Asi Pada Ibu Postpartum Di Rsud Jombang. Jurnal EDUNursing. 2019 Sep 5;3(2):68-77.

9. Kemenkes RI. Modul Orientasi Akupresur Bagi Petugas Puskesmas. Jakarta: Kementerian Kesehatan Republik Indonesia; 2012.

10. Nurafifah D, Kusbiantoro D. Effectiveness of Early Exercise Against Uterine Involution in Spontaneous Postpartum Patients. KEMAS: Jurnal Kesehatan Masyarakat. 2019 Oct 6;15(1):15-21.

11. Esfahani MS, Berenji-Sooghe S, Valiani M, Ehsanpour S. Effect of acupressure on milk volume of breastfeeding mothers referring to selected health care centers in Tehran. Iran J Nurs Midwifery Res. 2015;20(1):7-11.

12. Kemenkes RI. Buku Saku 1 Petunjuk Praktis Toga dan Akupresur. Jakarta: Kementerian Kesehatan Republik Indonesia; 2013.

13. Cholifah dkk. Akupresur pada Ibu Menyusui Meningkatkan Kecukupan Asupan Bayi di Kecamatan Mungkud. Jurnal Keperawatan Maternitas. 2014;3.

14. Rullynil dkk. Pengaruh Senam Nifas terhadap Penurunan Tinggi Fundus Uteri pada Ibu Post Partum di RSUP DR. M. Djamil Padang. Kesehatan Andalas. 2014;3.

15. Guyton A. Buku Ajar Fisiologi Kedokteran. Jakarta: EGC; 2010. 